

RESEARCH ARTICLE

\title{
COMPARATIVE EVALUATION OF THE EFFECT OF SALIVA SUBSTITUTE ON THE MICROHARDNESS OF THREE DIFFERENT DIRECT TOOTH COLOURED RESTORATIVE MATERIALS: AN IN VITRO STUDY.
}

Dr. Pranjal Sunil Walzade ${ }^{1}$, Dr. Sumanthini M V ${ }^{2}$, Dr. Vanitha U Shenoy ${ }^{3}$ and Dr. Rohini Mahajan ${ }^{4}$.

1. Post graduate student, Department of Conservative Dentistry and Endodontics, Mahatama Gandhi Mission's Dental College and Hospital, Navi Mumbai, Maharashtra, India.

2. Professor, Department of Conservative Dentistry and Endodontics, Mahatama Gandhi Mission's Dental College and Hospital, Navi Mumbai, Maharashtra, India.

3. Professor and Head, Department of Conservative Dentistry and Endodontics, Mahatama Gandhi Mission's Dental College and Hospital, Navi Mumbai, Maharashtra, India.

\section{Manuscript Info}

Manuscript History

Received: 12 April 2019

Final Accepted: 14 May 2019

Published: June 2019

Key words:-

Vickers microharness, saliva substitute, distilled water, RMGIC, KETAC N100, Filtek Z350 XT.

\section{Abstract}

Context: In patients using saliva substitute (SS) which would be a suitable aesthetic restorative material.

Aims: To evaluate and compare the effect of saliva substitute on the microhardness of direct tooth coloured restorative materials.

Settings and Design: This is an in vitro study for evaluation of Vickers microhardness (VM) where standard uniform disc- shaped specimens were immersed in a saliva substitute (SS) for 30 days.

Methods and Material: The tooth- colored restorative materials tested in this study were Group I- resin modified glass ionomer cement (RMGIC), Group II-light cured fluoride releasing restorative material (Ketac N100) and Group III-light cured resin composite restorative material (Filtek Z 350 XT). Forty- eight disc- shaped samples, 16 of each material were prepared. Samples belonging to respective groups were randomly divided into two subgroups with 8 samples each. Subgroup A was immersed in distilled water (DW) and subgroup B in saliva substitute (SS). In addition 3 samples of group I, II and III were prepared for scanning electron microscopic examination. VM value were calculated from the table of ISO 6507 standard. Pre and postimmersion microhardness measurements were made on the same surface of all samples.

Statistical Analysis Used: Normality of data obtained was tested using Kolmogorov-Smirnov and Shapiro-Wilk test, then parametric tests were used to compare the means between different groups. The level of significance was set at 5\% and the $p$ values less than 0.05 was considered statistically significant.

Results: All the restorative materials when immersed in SS showed statistically significant reduction $(\mathrm{p}<0.05)$ in microhardness. When the restorative materials were immersed in DW there was no substantial reduction in microhardness. Light cured resin composite restorative material (Filtek Z350 XT) showed the least reduction in microhardness followed by RMGIC and Ketac N 100. 
Conclusion: Among the materials tested Light cured resin composite restorative material showed maximum microhardness before and after immersion in DW and SS.

Copy Right, IJAR, 2019,. All rights reserved.

\section{Introduction:-}

Human saliva possess important physiological functions in moistening and protecting the oral hard and soft tissues. Certain conditions such as xerostomia, sjogrens syndrome and salivary gland hypofunction, chemoradiotherapy for head and neck carcinomas, antimuscarinic drugs and psychiatric disorders causes decrease in salivation ${ }^{1}$. The decreasing salivation causes oral dysfunction and promotes severe oral side effects such as reduced antibacterial function, lack of remineralization, reduced buffering capacity, difficulty in speaking, eating, swallowing and rampant caries of exposed dentin and cementum tooth surfaces. Moistening of the oral mucosa helps to relieve such symptoms in patients suffering from xerostomia and therefore, SS are often prescribed. ${ }^{1}$

The restoration of carious teeth in patients with xerostomia especially those who have undergone cervicofacial radiotherapy can be extremely demanding for both patients and dentists. Adhesive restorative materials such as light cured resin modified glass ionomer cement and its modifications, light cured resin composite material are usually recommended in these patients. For adequate performance of light cured restorative materials the material has to be adequately photopolymerised. The degree of photopolymerisation of resin composites influences its mechanical properties, solubility, dimensional stability, colour change and biocompatibility. Depths of cure and microhardness testing have been reliably and widely used to assess the relative degree of cure of resins. There are several methods such as scraping away unset material and measuring remaining specimen, determining top-bottom hardness and degree of conversion of double bonds in the polymer to assess this property ${ }^{2}$. Various studies have proved that the microhardness of restorative materials is influenced in the presence of various beverages consumed intraorally. ${ }^{3,4,5}$

There are no documented studies that have evaluated the effect of SS on the microhardness of direct tooth coloured restorative materials, hence aim of this study is to evaluate the effect of SS on the microhardness of three different direct tooth coloured restrorative materials. Null hypothesis tested was there is no difference in the effect of SS on the microhardness of three different direct tooth coloured restorative materials.

\section{Materials and methods:-}

Materials used in this study for VM testing were light cured resin modified glass ionomer cement (RM-GIC) (GC India Dental Pvt Ltd), light cured fluoride releasing restorative material (Ketac ${ }^{\mathrm{TM}} \mathrm{N} 1003 \mathrm{M}$ ESPE), light cured resin composite restorative material (Filtek Z350 XT 3M ESPE). The composition of materials is shown in Table 1. Experimental solutions used were DW $(\mathrm{pH}=7)$ and $\mathrm{SS}(\mathrm{pH}=6)$.

Group I - 16 samples of light cured resin modified glass ionomer cement (RM-GIC). (GC India Dental Pvt Ltd) Group II - 16 samples of light cured fluoride releasing restorative material. (Ketac ${ }^{\mathrm{TM}}$ N100 3M ESPE) Group III - 16 samples of light cured resin composite restorative material. (Filtek Z350 XT 3M ESPE)

In addition 3 samples of group I, II and III were prepared for scanning electron microscopic (SEM) examination.

Forty eight disk shaped samples, 16 of each material approximating the same shade (A2) was prepared using a polytetrafluoroethylene (Teflon) mould of $10 \mathrm{~mm}$ inner diameter and $2 \mathrm{~mm}$ depth. A mylar strip was placed on a clean glass slab over which a teflon mould was placed. The mould space was filled with direct tooth coloured restorative materials. Another mylar strip was placed on the upper surface of the mould and the material was flattened with a microscope glass slide in order to achieve a standardized surface finishing and to remove the excess of material. Following removal of excess material, the glass microscope slide was taken out gently leaving behind the mylar strip. LED curing light (Bluephae N, Ivoclar Vivadent) was used to cure the samples for a period of 40 seconds with the tip kept at a distance of $1 \mathrm{~mm}$. The intensity of the light curing unit was checked by an external Digital Light Meter (Bluedent BG Light LTD) before curing each sample. The samples was then retrieved from the mould. For identifying the top surface of sample a mark/ circular depression was made with no. $1 / 4^{\text {th }}$ round bur.

All the samples ( 48 for VM and 9 for SEM) were stored in DW at $37^{\circ} \mathrm{c}$ in an incubator within light proof containers for 24 hours. Further on, the samples belonging to respective groups were randomly divided into two subgroups, A 
and B based on the immersion solutions. Subgroup A was immersed in DW and subgroup B in SS with 8 samples each.

\section{Pre immersion VM testing:}

The samples were individually fixed in the VM apparatus (Reichert Austria make, Sr.No.363798) and positioned with the sample surface perpendicular to the indenter. A load of $100 \mathrm{~g}$ was applied to the surface of each sample for a dwell time of 15 seconds. Three indentations were made on the top surface of each sample. The three indentations were made with a minimum of $1 \mathrm{~mm}$ distance between them and to the periphery of the samples. The indentations were observed at $600 \mathrm{X}$ magnification. The average of the three readings was taken and VM value (VHN) were calculated from the table of ISO 6507 standard. Pre and post-immersion microhardness measurements were made on the same surface of all samples.

The samples belonging to Group IA, IIA and IIIA were immersed in glass vials containing $5 \mathrm{ml}$ of DW and samples of Group IB, IIB and IIIB were immersed in glass vials containing $5 \mathrm{ml}$ of SS. The samples were immersed for a period of thirty days; the solutions were changed and replaced with new solution every day.

\section{Post immersion VM testing:}

Determination of the post immersion hardness was carried out after 30 days in the same manner as the baseline VHN determination. The additional samples that were prepared for SEM analysis were also immersed in control and test solutions for a period of 30 days. The effect of both the test solutions on the surface micromorphology of the materials pre and post immersion was observed under SEM.

\section{Statistical analysis:}

The microhardness values obtained were tabulated and subjected to statistical analysis using SPSS software version 16 (SPSS Inc, Chicago, IL, USA). Normality of data was tested using Kolmogorov-Smirnov and Shapiro-Wilk test. The data was found to be normally distributed and hence parametric tests were used to compare the means between different groups. Further, Bonferroni multiple comparison test was applied to find out the exact significance for any two groups. The level of significance was set at $5 \%$ and the $p$ values less than 0.05 was considered statistically significant.

\section{Results:-}

The results of the study reveal that both the test solutions decreased the microharness of tested materials. The mean VHN and the standard deviation of the samples are presented in Table/Fig 4 and 5. The independent samples test of the baseline values of both DW and SS group showed that there was no statistically significant difference ( $p>0.05$ ) (Table/Fig 6,7 and 8). On comparison of the samples post immersion in the test solutions, there was statistically significant reduction $(\mathrm{p}<0.05)$ in microhardness values of samples belonging to group I, II and III when immersed in SS. ( $p=.003$ group I, $\mathrm{p}=.000$ for group II, $\mathrm{P}=.000$ for group III, Table/Fig 6,7 and 8 ). However the results of the Bonferroni multiple comparison test shows that there was significant difference $(\mathrm{p}=.047)$ when group II (A light cured fluoride releasing restorative material-Ketac N 100) was compared against Group III (light cured resin composite restorative material-Filtek Z350 XT) when immersed in SS whereas all other pairs shows no significant difference. (p value >0.05). (Table/Fig 9).

SEM micrograph showed changes in surface topography of all samples after immersion in both DW and SS. On comparison, smoothest surface was observed in group I (RMGIC) (Table/Fig 10) follwed by group III. (Filtek Z350XT) (Table/Fig 10). SS brought about greater changes in surface topography than compared to DW. The SEM micrographs of samples belonging to Ketac N100 revealed voids initially (before immersion) and also exhibited greater surface irregularities and pitting. (Table/Fig 10).

\section{Discussion:-}

In patients with hyposalivation due to reduced quantity of saliva they present difficulty in speaking, eating, swallowing and rampant caries of exposed tooth surfaces ${ }^{6,7,8}$. An increased prominence of cariogenic microorganisms leads to the rapid circumferential progress of cervical lesions which is worsened by poor oral hygiene. ${ }^{9}$ Although the treatment of xerostomia is very subjective a first-line of management is to ameliorate the dehydration in the mouth by stimulating and/or substituting for the secretion of saliva ${ }^{10}$. The artificial saliva 
products available contain several inorganic salts found in human saliva and antimicrobial agents to humidify and/or prevent bacterial infection in the dehydrated mucosa. ${ }^{8,11}$

Teeth are often restored with adhesive tooth coloured restorative materials especially in the non-stress bearing area as they do not involve extensive tooth structure removal for retaining the restoration. Due to high caries index, a fluoride releasing restorative material is generally preferred. SS may affect the integrity of restorative materials. The restorative materials evaluated in the study are light cured resin modified glass ionomer cement (RM-GIC), light cured fluoride releasing restorative material (Ketac N 100), light cured resin composite restorative material (Filtek Z350 XT).

Depths of cure and microhardness testing have been reliably and widely used to assess the relative degree of cure of resins. There are several methods to assess this property and VM test is one of them. The degree of photopolymerisation of resin composites influences its mechanical properties, solubility, dimensional stability, colour change and biocompatibility. Measurement of surface microhardness of composite resins is a useful method to indirectly evaluate the degree of polymerization. ${ }^{12}$ According to ISO 4049:2000, to achieve the acceptable degree of polymerization composite resins have to meet the requirement of $\geq 80 \%$ bottom/top percentage microhardness at 2 $\mathrm{mm}$ depth. ${ }^{12}$ Various studies have proved that the microhardness of restorative materials is influenced in the presence of various beverages consumed intraorally. ${ }^{3,4,6}$

One of the most important properties is the material's hardness, which correlates well with compressive strength, resistance to intra-oral softening, and degree of conversion. ${ }^{13,14}$

The results of the study reveal that all three restorative materials showed a significant surface hardness reduction after 30 days immersion period irrespective of the solution used. 30 days interval was chosen with an assumption that the patient will have 16 waking hours on an average and SS may be in contact with oral tissues approximately for 12 hours. In these 12 hours SS will be in continuous contact with teeth and the restorations. Hence Immersion for 30 days which would have for 720 hours will correspond to 60 days of intraoral application ${ }^{15}$.

However, specimens that were immersed in SS demonstrated greater surface microhardness reductions when compared to the specimens immersed in DW after a 30 day evaluation period. Thus the null hypothesis was rejected. The decrease in the microhardness could be attributed to material deterioration by way of liquid absorption within the resin matrix.

Mayworm $\mathrm{C} \mathrm{D}^{16}$ have Confirmed that VM of the composites (Esthet-X-Dentsply and Filtek Supreme-3M) decreases after storage in artificial saliva. Nair $\mathrm{S} \mathrm{R}^{17}$ concluded that greatest colour stability and Vicker's Hardness was seen in Filtek Z350 XT followed by Tetric N Ceram and least values were seen in G aenial Universal Flo after storage in instant coffee for 72 hours. Somayaji S K in $2016^{18}$ studied effects of acidic Beverages such as Appy fizz, Nimbooz, and Thumbs Up on microhardness of Nanohybrid Composite, Giomer, and Microhybrid Composite and found that microhardness of materials was reduced after 7 and 14 days, but significant difference was seen after 21 days. Solomon $\mathrm{R}^{19} \mathrm{~V}$ concluded that a $10 \%$ carbamide peroxide bleaching agent had an adverse effect on the micro hardness of nanofilled and hybrid types of resin-based composite materials compared with the micro hybrid type.

Many variables affect the microhardness of light cured restorative materials such as amount of light energy received on the top and bottom surfaces of a composite resin restoration, such as the design and size of the light guide, distance of the light guide tip from the composite resin, power density, exposure duration, shade and opacity of the composite resin, increment thickness, and material composition. ${ }^{20}$ Sample preparation was standardized in order to minimize the effects caused by these variables.

DW is obtained from water by a distillation process and contains only pure water molecules. ${ }^{21}$ It can be assumed that any changes observed in an experiment will be a result of the unique properties of the material and not the DW. Hence DW was chosen as a control solution. However, storage in DW also decreased the surface hardness of the restorative materials studied though it was statistically insignificant. This could be because water serves as a plasticizing molecule within the composite matrix, causing a softening of the polymer resin component resulting in swelling of the network and reducing the frictional forces between polymeric chains. ${ }^{22}$

Nanofilled composite showed maximum microhardness values perhaps due to its filler particle size which ranges from $0.005-0.01$ microns. Highly translucent materials are produced by the use of nanomeric particles this is because 
the size of use of the particles is less than that of the wave length of visible light (400-800 nm). These very small particles do not react with visible light and don't produce scattering thereby resulting in significant absorption of light leading to improvement in modulus of elasticity, depth of cure and aesthetics. ${ }^{23}$ In addition the surface area to volume ratio of the nanoparticles is quite large. The sizes of the smallest nanoparticles approach those of polymer molecules so they can form a molecular scale interaction with the host resin matrix. ${ }^{24}$

Nanofilled composite materials contain Bis-EMA and a reduced amount of TEGDMA, both characteristics promote better resistance to the action of chemical substances. On the contrarary to Bis-GMA and UDMA, which are known to be inclined to softening after exposure to chemical agents. ${ }^{25}$ Therefore, differences in chemical composition among the RMGIC and Ketac N 100 and resin-based composites might have contributed to the differences in surface hardness among these materials.

Reasons for the reduction of microhardness in RMGIC may be due to selective attack on the poly salt matrix between the residual particles and release of fluoride from the material following immersion in acidic environments. ${ }^{26}$ According to Wilde et al the fluoride ion release occurs during dissolution of the matrix-forming constituents within the set material. The reduction in the microhardness of Filtek Z350 XT in both DW and SS could be attributed to either hydrolytic breakdown of the silane -filler particle bond or hydrolytic degradation of the filler particles. $^{27}$

According to SEM results of the present study, all the materials tested showed changes in surface topography after immersion in both DW and SS for 30 days. When Scanning electron microscope images of RMGIC (fig. 10 a ,b, c), Ketac N100 (fig. 10 d,e,f) and Filtek Z350 XT (fig. 10 g,h,i) were compared, smoothest surface was shown by light cured resin composite restorative material (group III). SS brought about greater changes in surface topography than compared to DW. The SEM micrographs of samples belonging to Ketac N100 revealed voids initially (before immersion) and also exhibited more surface irregularities and pitting (fig. 10 d,e,f) Surface topography of Filtek Z350 XT was smoother as compred to KetacN 100 in both DW and SS (fig. 10 g,h,i). Surface irregularities are probably caused because of erosion of resin matrix due to the action of the experimetal liquids. Similar findings were reported by authors Hashemikamangar SS et $\mathrm{al}^{28}$. Degradation of inorganic fillers may play an important role in surface microhardness ${ }^{28}$. Further on as the SEM photomicrograph findings can be correlated with the microhardness values, it was observed that samples of light cured resin composite restorative material (group III) had shown the maximum microhardness values and smoothest surface followed by resin modified glass ionomer (group I) and lastly Ketac N100 light cured restorative material (group II) which showed the most irregular surface with voids and pitting.

SSs can be categorized into solutions based on CMC, mucin, and linseed. Most commercially available SSs are based on CMC. It is a polymer derived from natural cellulose and used in SS formulation as a thickening agent. CMC produces crystal clear gel products and thickens the aqueous phase as well as renders good water retention and film formation ${ }^{29}$. This property of water retention and film formation of CMC based SS could have probably resulted in greater reduction in microhardness of restorative materials when immersed for 30 days.

It was observed that light cured resin composite (Filtek Z 350 XT) performed better than nanofilled glass ionomer cement and resin modified glass ionomer cement materials. However light cured composite resin restorations are more suspectible to secondary caries. Hence the patients should be instructed for maintaining the oral hygiene. In addition, they require frequent topical fluoride application and better SS formulations that will not interfere in the physical and mechanical properties of restorative materials. There by enhancing the clinical longievity of the restorations. Further in vitro and long term controlled clinical trials using various agents that are used as SS are needed to investigate and elucidate the effects of these solutions on the property and longevity of the restorative materials.

The limitations of the study include the in vitro study design where the experimental conditions cannot completely replicate the intraoral environment such as temperature changes, $\mathrm{pH}$ level, salivary enzymes and the ionic composition of food or beverages which would have a concerted effect on the properties of restorations. Moreover the number of times a person uses SS is highly subjective and is variable as it depends on the degree of dryness of mouth experienced by the patient. Furthermore only one SS was considered to evaluate the changes in microhardness values. Other types of SS were not considered in this study. 


\section{Conclusion:-}

Within the limitation of this in vitro study it was observed that all the restorative materials when immersed in SS showed reduction in microharness while DW showed no substantial effect on microhardness. Light cured resin composite restorative material showed the least reduction in microhardness followed by RMGIC and Ketac N 100 when subjected to SS challenge. Therefore in xerostemic patients with optimum oral hygiene light cured nanofilled resin caomposites restorations may be placed when they are prescribed SS.

Table/Fig no.1:-

\begin{tabular}{|c|c|}
\hline $\begin{array}{l}\text { Tooth colored restorative } \\
\text { material }\end{array}$ & Composition \\
\hline $\begin{array}{l}\text { - A light cured resin } \\
\text { modifiedglass } \\
\text { ionomer cement - } \\
\text { RM-GIC } \\
\text { - GC TYPE II } \\
\text { (GC Corporation Tokyo } \\
\text { Japan) }\end{array}$ & $\begin{array}{l}\text { - Powder- Fluoroaluminosilicate glass and a microencapsulated } \\
\text { potassium persulphate and ascorbic acid catalyst system, } \\
\text { camphoroquinone. } \\
\text { Liquid - polycarboxylic acid modified with pendant methacrylate } \\
\text { groups, HEMA, tartaric acid. }\end{array}$ \\
\hline $\begin{array}{l}\text { A light cured } \\
\text { nanoionomer } \\
\text { restorative material - } \\
\text { Ketac N-100 } \\
\text { - (3M ESPE Dental } \\
\text { products USA ) }\end{array}$ & $\begin{array}{l}\text { - Aqueous paste -acidic polyalkenoic acid, reactive resins and nano } \\
\text { fillers } \\
\text { - Non aqueous paste -Fluoroaluminosilicate(FAS) glass, reactive resins, } \\
\text { and nano fillers } \\
\text { - Filler content ( } 69 \%) \\
\text { 27\% FAS glass (acid and free radically reactive), } 42 \% \text { methacrylate } \\
\text { functionalized nano fillers (acid and free radically reactive }\end{array}$ \\
\hline $\begin{array}{l}\text { A light cured resin } \\
\text { composite restorative } \\
\text { material - Filtek Z } \\
350 \text { XT } \\
\text { (3M ESPE Dental } \\
\text { products USA ) }\end{array}$ & $\begin{array}{l}\text { - Dimethacrylates, such as Bis-GMA, Bis-EMA, UDMA or TEGDMA, } \\
\text { inorganic filler- } \mathrm{SiO} 2 \text {, silicates or ceramics, dispersed within the } \\
\text { matrix. } \\
\text { coupling agents- organosilanes, camphorquinone and tertiary amine, } \\
\text { pigments, inhibitors or stabilizers. }\end{array}$ \\
\hline 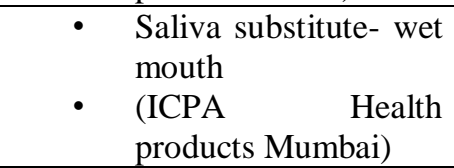 & $\begin{array}{l}\text { - Sodium carboxymethyl cellulose, xylitol, potassium chloride, calcium } \\
\text { chloride, potassium phosphate, potassium thiocyanate, glycerine, } \\
\text { sodium saccharin, parabens and a flavouring agent }\end{array}$ \\
\hline
\end{tabular}

Table/Fig 2: -Image of the indentation (600 X magnification)

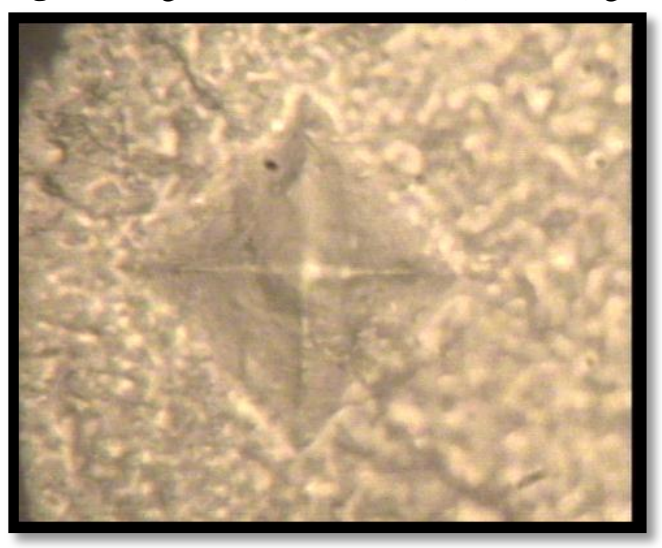

Table/Fig 3:-Vickers microindentation images

1. groups I, ( a- Preimmersion, d- post 30 day immersion in distilled water, g post 30 day immersion in saliva substitute) 
2. groups II, ( $b$ Preimmersion, e- post 30 day immersion in distilled water, $h$ - post 30 day immersion in saliva substitute)

3. groups III, ( c- Preimmersion, f- post 30 day immersion in distilled water, i- post 30 day immersion in saliva substitute)

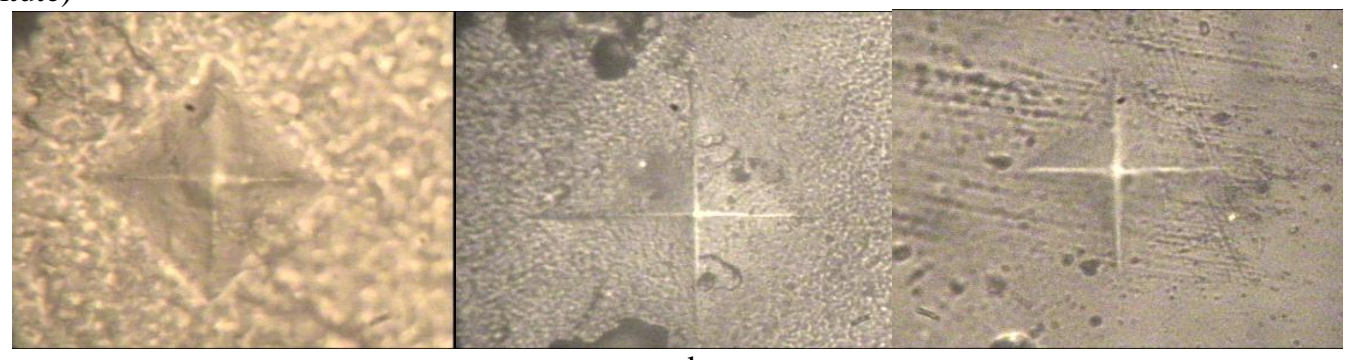

a

$\mathrm{b}$

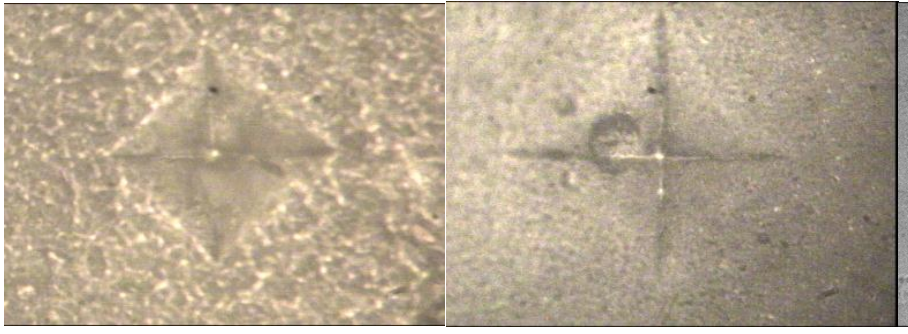

d

$\mathrm{e}$

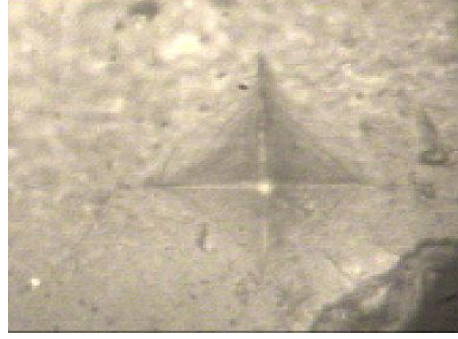

g

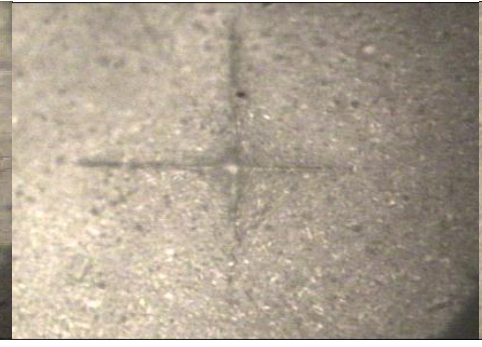

$\mathrm{h}$

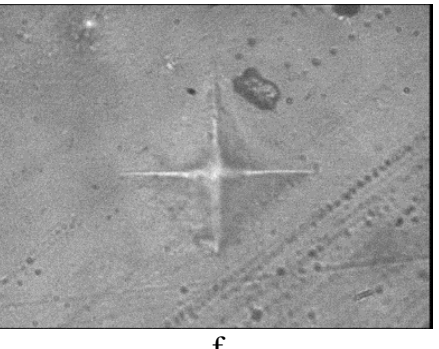

Table/Fig 4:-Descriptive statistics Comparison of before and after when immersed in distilled water

\begin{tabular}{|c|c|c|c|c|c|}
\hline & & Mean & N & Std. Deviation & Std. Error Mean \\
\hline \multirow{2}{*}{ Group I } & Before & 64.3362 & 8 & 1.80145 & .63691 \\
\cline { 2 - 6 } & After & 59.7575 & 8 & .43827 & .15495 \\
\hline \multirow{2}{*}{ Group II } & Before & 54.8538 & 8 & 3.76533 & 1.33124 \\
\cline { 2 - 6 } & After & 50.7400 & 8 & 2.60800 & .92207 \\
\hline \multirow{2}{*}{ Group III } & Before & 75.5838 & 8 & 2.18171 & .77135 \\
\cline { 2 - 6 } & After & 71.2100 & 8 & 1.14413 & .40451 \\
\hline
\end{tabular}

Table/Fig 5:-Descriptive statistics Comparison of before and after immersion in Saliva substitute

\begin{tabular}{|c|c|c|c|c|c|}
\hline & & Mean & N & Std. Deviation & Std. Error Mean \\
\hline \multirow{2}{*}{ Group I } & Before & 63.2188 & 8 & 1.24149 & .43893 \\
\cline { 2 - 6 } & After & 55.9700 & 8 & 2.93267 & 1.03685 \\
\hline \multirow{2}{*}{ Group II } & Before & 54.8738 & 8 & 2.31954 & .82008 \\
\cline { 2 - 6 } & After & 43.9962 & 8 & 2.42773 & .85833 \\
\hline \multirow{2}{*}{ Group III } & Before & 74.4825 & 8 & 1.55382 & .54936 \\
\cline { 2 - 6 } & After & 67.7262 & 8 & 1.62414 & .57422 \\
\hline
\end{tabular}

Table/Fig 6:-Independent Samples Test for Group I

\begin{tabular}{|l|c|c|c|c|}
\hline & t-test & df & p-value & Mean Difference \\
\hline
\end{tabular}




\begin{tabular}{|l|l|l|l|l|}
\hline Before & 1.445 & 14 & .171 & 1.11750 \\
\hline After & 3.613 & 14 & .003 & 3.78750 \\
\hline
\end{tabular}

Table/Fig 7:-Independent Samples Test for Group II

\begin{tabular}{|l|l|l|l|l|}
\hline & \multicolumn{1}{|c|}{ t-test } & \multicolumn{1}{c|}{ df } & \multicolumn{1}{c|}{ p-value } & \multicolumn{1}{c|}{ Mean Difference } \\
\hline Before & -.013 & 14 & .990 & -.02000 \\
\hline After & 5.353 & 14 & .000 & 6.74375 \\
\hline
\end{tabular}

Table/Fig 8:-Independent Samples Test for Group III

\begin{tabular}{|l|l|l|l|l|}
\hline & \multicolumn{1}{|c|}{ t-test } & \multicolumn{1}{c|}{ df } & \multicolumn{1}{c|}{ p-value } & Mean Difference \\
\hline Before & 1.163 & 14 & .264 & 1.10125 \\
\hline After & 4.960 & 14 & .000 & 3.48375 \\
\hline
\end{tabular}

Table/Fig 9:-Bonferroni multiple comparison test for saliva substitute:

\begin{tabular}{|c|c|c|c|c|c|}
\hline \multirow{2}{*}{$\begin{array}{c}\text { Dependent } \\
\text { Variable }\end{array}$} & \multirow[t]{2}{*}{ (I) } & \multirow[t]{2}{*}{ (J) } & \multirow[t]{2}{*}{ Mean Difference (I-J) } & \multirow[t]{2}{*}{ p-value } & \\
\hline & & & & & Interpretation \\
\hline \multirow[t]{6}{*}{ Before } & \multirow[t]{2}{*}{ Group I } & Group II & $8.34500^{*}$ & .000 & Significant \\
\hline & & Group III & $-11.26375^{*}$ & .000 & Significant \\
\hline & \multirow[t]{2}{*}{ Group II } & Group I & $-8.34500^{*}$ & .000 & Significant \\
\hline & & Group III & $-19.60875^{*}$ & .000 & Significant \\
\hline & \multirow[t]{2}{*}{ Group III } & Group I & $11.26375^{*}$ & .000 & Significant \\
\hline & & Group II & $19.60875^{*}$ & .000 & Significant \\
\hline \multirow[t]{6}{*}{ After } & \multirow[t]{2}{*}{ Group I } & Group II & $11.97375^{*}$ & .000 & Significant \\
\hline & & Group III & $-11.75625^{*}$ & .000 & Significant \\
\hline & \multirow[t]{2}{*}{ Group II } & Group I & $-11.97375^{*}$ & .000 & Significant \\
\hline & & Group III & $-23.73000^{*}$ & .000 & Significant \\
\hline & \multirow[t]{2}{*}{ Group III } & Group I & $11.75625^{*}$ & .000 & Significant \\
\hline & & Group II & $23.73000^{*}$ & .000 & Significant \\
\hline \multirow[t]{6}{*}{ DIFFERENCE } & \multirow[t]{2}{*}{ Group I } & Group II & -3.62875 & .092 & NS \\
\hline & & Group III & .49250 & 1.000 & NS \\
\hline & \multirow[t]{2}{*}{ Group II } & Group I & 3.62875 & .092 & NS \\
\hline & & Group III & $4.12125^{*}$ & .047 & Significant \\
\hline & \multirow[t]{2}{*}{ Group III } & Group I & -.49250 & 1.000 & NS \\
\hline & & Group II & $-4.12125^{*}$ & .047 & Significant \\
\hline
\end{tabular}

Table/ Fig 10:-

1. Scanning electron micrograph images at $1000 \mathrm{X}$ magnification of the samples belonging to groups I, ( aPreimmersion, b- post 30 day immersion in distilled water, c- post 30 day immersion in saliva substitute)

2. Group II ( d- Preimmersion, e- post 30 day immersion in distilled water , f- post 30 day immersion in saliva substitute)

3. Group II ( g- Preimmersion, h- post 30 day immersion in distilled water , i- post 30 day immersion in saliva substitute) 

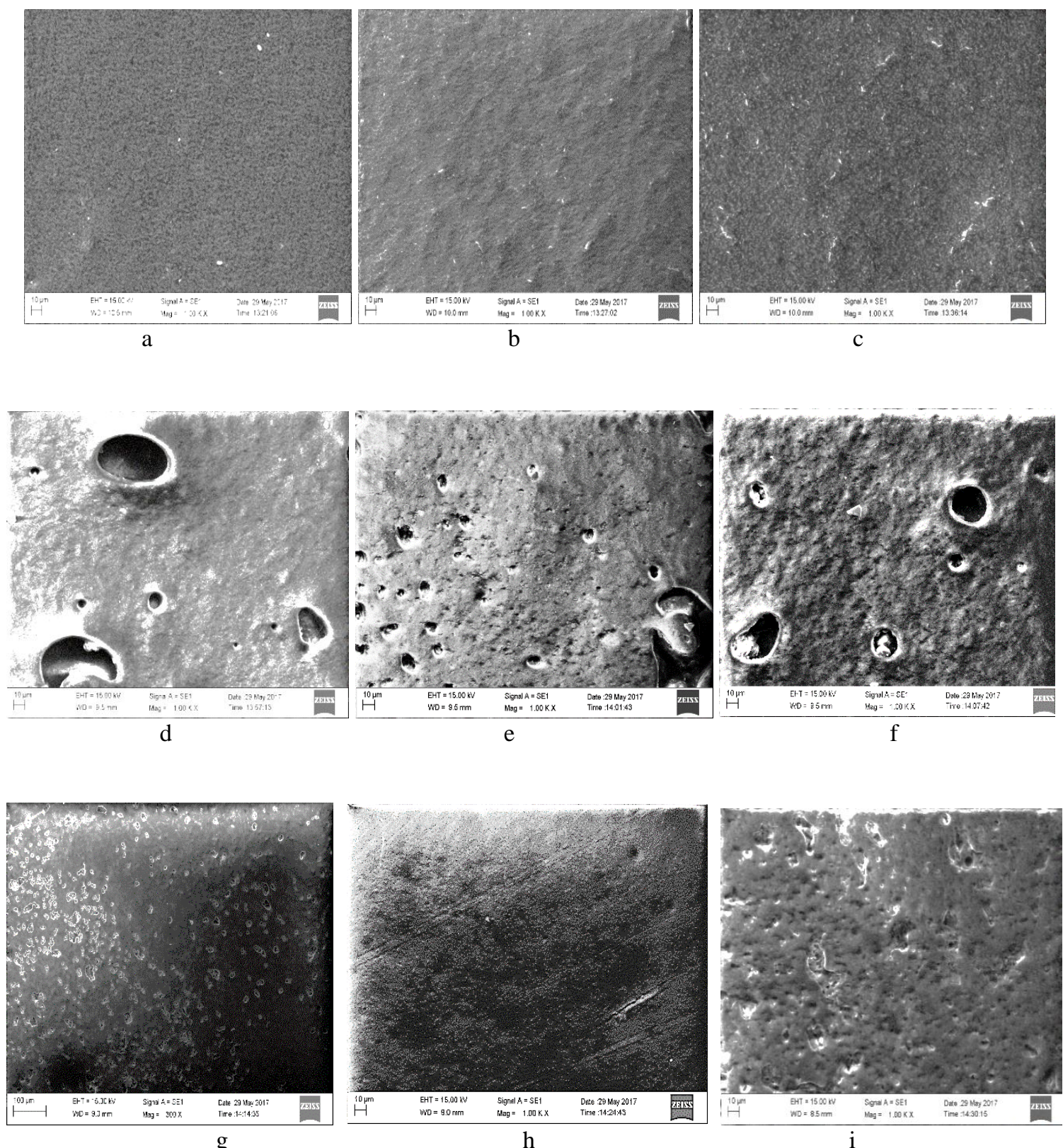

Table/Fig 11:-Bar graph comparing the mean hardness values of samples before and after immersion in distilled water 


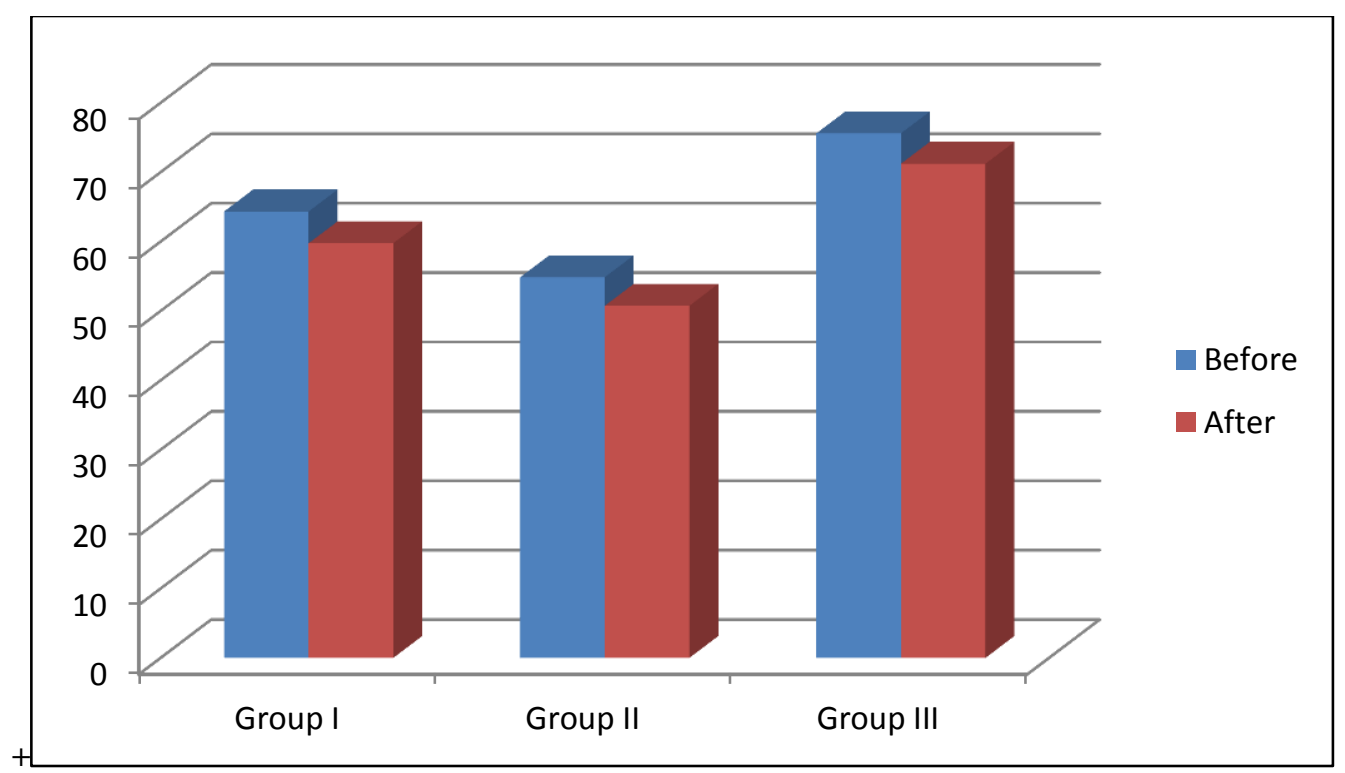

Table/Fig 12:-Bar graph comparing the mean hardness values of samples before and after immersion in saliva substitute

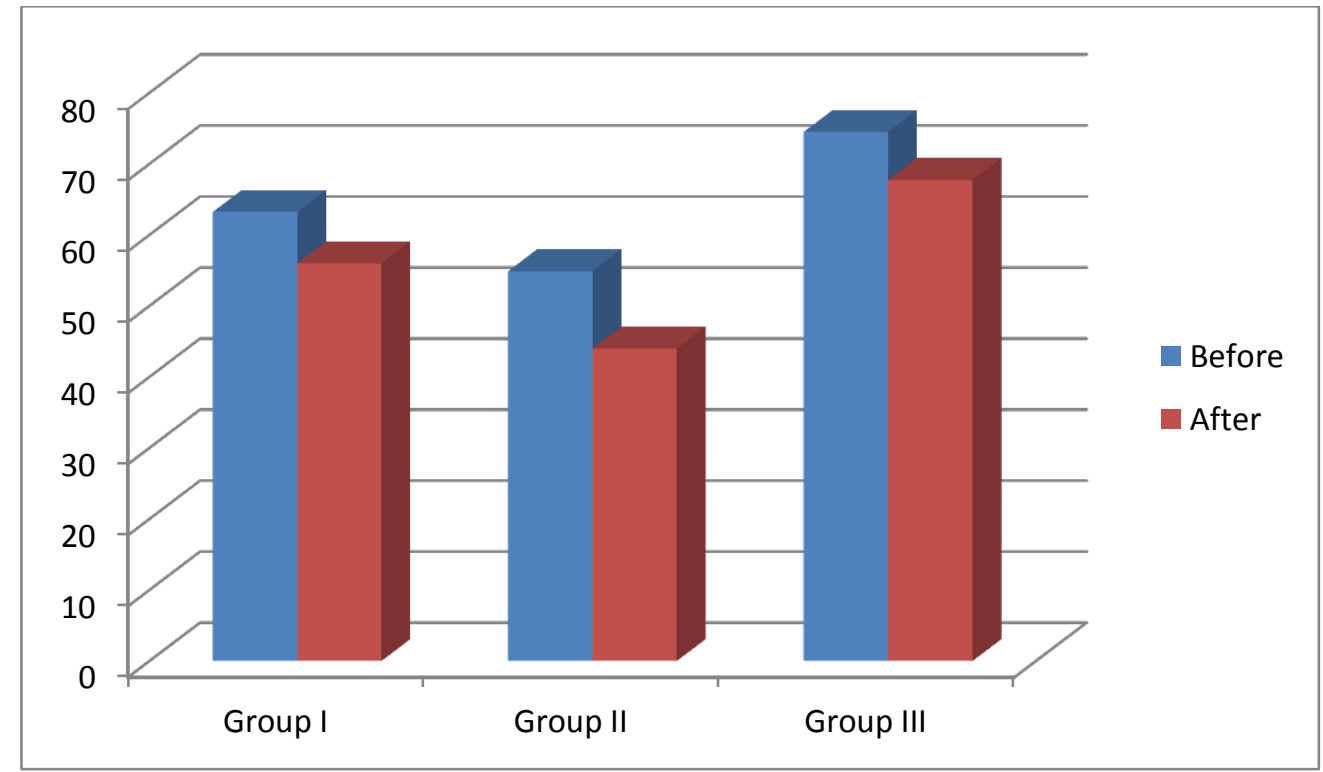




\section{References:-}

1. Meyer-Lueckel H, Tschoppe P, Kielbassa A M. Linseed based saliva substitutes and their effect on mineral dissolution of predemineralized bovine dentin in vitro. J Dent 2006;34:751-756.

2. Miljković N, Dačić S, Karuntanović T, Igić M, Dačić M, Simonović D. The Influence of Different Light Curing Modes on the Depth of Cure of the Composite Resin. Oper dent 2008;33(4):408-412

3. Gharatkar A A, Irani R , Shiraguppi V, Hegde V. Effect of cola, orange juice, and wine on surface microhardness of nano-composites: An in vitro study. J Dent Orofac Res. 2014;10(1):16-20.

4. Yanikoğlu N, Duymuş Y Z and Yilmaz B. Effect of different solutions on the surface hardness of composite resin materials. Dental Materials Journal 2009;28(3):344-351

5. Kooi TJ, Tan QZ, Yap AU, Guo W, Tay KJ, Soh MS. Effects of food-simulating liquids on surface properties of giomer restoratives. Oper Dent. 2012;37(6):665-71.

6. Samarawickrama DY. Saliva substitutes: how effective and safe are they? Oral

7. Dis. 2002;8:177-179.

8. Van der Reijden WA, van der Kwaak JS, Veerman ECI, Nieuw Amerongen AV.

9. Analysis of the concentration and output of whole saliavary constituents in patients

10. with Sjogren's syndrome. Eur J Oral Sci. 1996;104:335-340.

11. Kang M, Park H, Jun J, Son M, Kang M J. Facilitated saliva secretion and reduced

12. oral inflammation by a novel artificial saliva system in the treatment of salivary

13. hypofunction. Drug Design, Development and Therapy 2017;11: 185-191

14. Pedersen AM, Bardow A, Jensen SB, Nauntofte B. Saliva and gastrointestinal functions of taste, mastication, swallowing and digestion. Oral Dis. 2002;8:117-129

15. Hu JY, Chen XC, Li YQ, Smales RJ, Yip KH. Radiation induced root surface caries restored with glass ionomer cement placed in conventional and ART cavity preparations: Results at two years. Australian Dental Journal 2005; 50(3):186-190.

16. Levine MJ. Development of artificial salivas. Crit Rev Oral Biol Med. 1993;4:279-286.

17. Voltarelli F R, Daroz C B , Alves M C, Peris A R, Marchi G M. Effect of different light curing devices and aging procedures on composite knoop microhardness Braz Oral Res 2009;239(4):473-479

18. Badra VV, Faraoni JJ, Ramos RP, Palma-Dibb RG. Influence of different beverages on the microhardness and surface roughness of composite resins. Oper Dent. 2005;30:213-9.

19. Uhl A, Mills RW, Jandt KD. Photoinitiator dependent composite depth of cure and Knoop hardness with halogen and LED light curing units. Biomaterials. 2003;24:1787-95.

20. Margasahayam S V, Walzade P S, Shenoy V U Comparative evaluation of the effect of a saliva substitute on the color stability of three different direct tooth-colored restorative materials: An in vitro spectrophotometric study. Indian J Dent Sci 2018;10(3):127-132

21. Mayworm C D, Camargo S S, Bastian F L. Influence of artificial saliva on abrasive wear and microhardness of dental composites filled with nanoparticles. Journal of Dentistry 2008 36(9):703-10

22. Nair S R, Niranjan N T, Jayasheel A, Suryakanth D B. Comparative Evaluation of Colour Stability and Surface Hardness of Methacrylate Based Flowable and Packable Composite -In vitro Study. Journal of Clinical and Diagnostic Research 2017; 11(3): 51-54.

23. Somayaji S K, Amalan A, Ginjupalli K. Effect of Different Acidic Beverages on Microhardness of Nanohybrid Composite, Giomer, and Microhybrid Composite. World Journal of Dentistry 2016; 7(3):126-128.

24. Solomon R V, Byragoni C, Jain A, Juvvadi Y, Babu R. An in vitro evaluation of microhardness of different direct resin-based restorative materials on using $10 \%$ carbamide peroxide gel as a bleaching agent. Journal of Oral Research and Review 2016; 8(2):59-65.

25. Aguiar FH, Lazzari CR, Lima DA, Ambrosano GM, Lovadino JR. Effect of light curing tip distance and resin shade on microhardness of a hybrid resin composite. Braz Oral Res. 2005;19(4):302-6.

26. Sciencing.com/distilled-good-control-science-projects-7418493.html

27. Zuryati, A G, Qian, O Q, \& Dasmawati, M. Effects of home bleaching on surface hardness and surface roughness of an experimental nanocomposite. Journal of Conservative Dentistry : JCD 2013; 16(4):356-361.

28. Lombardini M, Chiesa M, Scribante A, Colombo M, and Poggio C. The influence of polymerization time and depth of cure of six commercial resin composites by Vickers microhardness. Dental Research Journal 2012;9(6):735-740

29. Sakaguchi R, Powers J. Craig's Restorative Dental Materials. Philadelphia, PA: Elsevier Inc; 2012.

30. Zuryati, A G, Qian, O Q, \& Dasmawati, M. Effects of home bleaching on surface hardness and surface roughness of an experimental nanocomposite. Journal of Conservative Dentistry : JCD 2013; 16(4):356-361. 
31. Fatima N, Abidi S Y, Qazi F R, Jat S A. Effect of different tetra pack juices on microhardness of direct tooth colored-restorative materials. The Saudi Dental Journal 2013; 25: 29-32.

32. Sharafeddin F, Sharifi E. The effect of microwave/laboratory light source postcuring technique and wet aging on microhardness of composite resin. Dental Research Journal 2013;10(3):370-375

33. Hashemikamangar S S, Pourhashemi S J , Kiomarsi M N, and Kharazifard M J. Effect of organic acids in dental biofilm on microhardness of a silorane-based composite Restor Dent Endod. 2015 Aug; 40(3): 188-194.

34. Vadcharavivada S, Boonroungb T. Effects of two carboxymethylcellulose-containing saliva substitutes on post -radiation xerostomia in head and neck cancer patients related to quality of life. Asian Biomed 2013;7:193-202. 